\title{
Pathway and regulation of phosphate translocation to the pods of soybean explants
}

\author{
Peter M. Neumann and Larry D. Noodén
}

Neumann, P. M. and Noodén, L. D. 1984. Pathway and regulation of phosphate translocation to the pods of soybean explants. - Physiol. Plant. 60: 166-170.

\begin{abstract}
We investigated the degree to which developing fruit compete directly with leaves for mineral nutrients, e.g. phosphate coming up from the roots. When soybean (Glycine max (L.) Merrill cv. Anoka) explants cut at mid-late podfill were given a 15 -min pulse of ${ }^{32} \mathrm{Pi}$ via the cut stem and then transferred to distilled water, $75 \%$ of the ${ }^{32} \mathrm{P}$ accumulated in the leaves and $21 \%$ in stem and petiole during the first hour. The amount of ${ }^{32} \mathrm{P}$ entering the seeds was low $(1 \%)$ initially, but thereafter increased to $30 \%$ in $48 \mathrm{~h}$. An accumulation of ${ }^{32} \mathrm{P}$ in the seed coats preceded its entry into the embryos. Distuption (with hot steam) of the phloem between the leaf and the pods after pulse labelling indicated that more than $80 \%$ of the ${ }^{32} \mathrm{Pi}$ pulse moved to the leaf before redistribution to the pods. Increasing "sink" size by adjusting the pod load from 1 to $2-3$ did not increase the ${ }^{32} \mathrm{P}$ accumulated by the pods proportionally. Conversely, excision of the seeds after pulse labelling did not prevent translocation of ${ }^{32} \mathrm{P}$ out of the leaves. These results singgest that the rate of transport of phosphate to the pods at mid-late podfill is controlled primarily by factors in the leaves. The results are consistent with the observation that the relative size of the sink (pod load) does not regulate leaf senescence.
\end{abstract}

Additional key words - Glycine max, monocarpic senescence, phloem, xylem.

P. M. Neumann (reprint requests), Plant Physiology Lab., Fac. of Agricultural Eng., Technion-Israel Institute of Technology, Haifa 32000, Israet; L. D. Noodén, Botany Dept, Diw. of Biological Sciences, Univ. of Michigan, Ann Arbor, Mi. 48109, USA.

\section{Introduction}

The developing reproductive structures in monocarpic and other plants seem to monopolize the supply of new assimilates and thereby influence the senescence of the vegetative parts, especially the leaves (Noodén 1980). Minerals and nitrogenous compounds are supplied from the roots via the xylem, and these nutrients may either be taken directly from the xylem by developing fruit or may enter leaves first. The indirect route via the leaves is suggested by many reports (Hanway and Weber 1971, Lewis and Pate 1973, Hocking and Pate 1977, McNeil et al. 1979).

Knowledge of the routing of assimilates from the roots to the developing fruit is important in understanding the mechanism by which developing fruits cause monocarpic senescence. Some studies show that developing reproductive structures divert new assimilates away from vegetative parts (Noodén 1980). However, two indirect lines of evidence (Lindoo and Noodén 1977, Noodén et al. 1978) suggest that nutrient diversion is not the mechanism by which the developing soybean seeds induce monocarpic senescence in soybean. An additional direct test of pod capacity to divert nutrient supplies in the xylem away from the leaves seemed important.

This study was initiated to determine: i) the pathway for movement of a currently assimilated mineral ( ${ }^{32} \mathrm{P}-\mathrm{KH}_{2} \mathrm{PO}_{4}$ ) from the roots to the pods, and ii) whether or not the transfer of phosphate to the pods is controlled by the size of the seed "sink". We have employed the recently described soybean explant system (Neumann and Noodén 1983, Neumann et al. 1983) to analyze these questions relating to control of

Received 15 June, 1983; revised 29 September, 1983 
leaf senescence and seed development in soybean. A preliminary report of these results has been given (Neumann and Noodlén 1981).

\section{Materials and methods}

Plant material. Soybeans (Glycine max (L.) Merrill cv. Anoka) were germinated and grown for $3-4$ weeks in pots on a greenhouse bench with supplementary illumination $\left(850-900 \mu \mathrm{mol} \mathrm{m} \mathrm{m}^{-2} \mathrm{~s}^{-1}\right.$ in the photosynthetically active radiation region from high pressure sodium vapor lamps) so that the diurnal light period always exceeded $14 \mathrm{~h}$ and flowering was prevented. Plants were then transferred to controlled environment chambers under $10 \mathrm{~h}$ (short) days to promote flowering. Conditions in chambers were as previously described by Lindoo and Noodén (1976). The SD numbers in all figures refer to short-day cycles undergone by plants.

Preparation of soybean explants. Explants consisting of a $10-\mathrm{cm}$ stem section, one node and a leaf were excised from the mid-sections of soybean plants at mid to late podfill (Neumann et al. 1983). Pod number was adjusted to either 1 or $2-3$ pods per node $24 \mathrm{~h}$ before excision of explants. Explants were allowed to equilibrate in chambers with the cut base of the stem in distilled water for $60 \mathrm{~min}$ before pulse labelling with ${ }^{32} \mathrm{Pi}$. In some experiments, small incisions were made in the carpel of pulse-labelled explants after $1 \mathrm{~h}$ of chase and the seeds were excised. The carpel was then resealed with lanolin; this procedure inflicts minimal damage when properly done (Lindoo and Noodén 1977). Stomatal resistances in explants were equivalent to those of intact plants during the ${ }^{32} \mathrm{P}$ pulse (Neumann et al. 1983).

Pulse labelling of explants with ${ }^{32} P i$. Explants were transferred to flasks containing 0.1 or $1.0 \mathrm{~m} M \mathrm{KH}_{2} \mathrm{PO}_{4}$ with high specific activity $\mathrm{H}_{3}{ }^{32} \mathrm{PO}_{4}$ at $3.7 \times 10^{4} \mathrm{~Bq} \mathrm{ml}^{-1}$. Following a $15 \mathrm{~min}$ labelling period under conditions of high transpiration, the explants were removed from the ${ }^{32} \mathrm{Pi}$ solution and the stems rinsed in a large volume of unlabelled $1.0 \mathrm{mMKH} \mathrm{KH}_{2} \mathrm{PO}_{4}$. The bottom $4 \mathrm{~cm}$ of the 10 $\mathrm{cm}$ long stems were then cut off to remove residual surface contamination, and the explants were returned to flasks containing distilled water for incubation periods of $1-48 \mathrm{~h}$.

Analysis of plant material. Groups of 3 explants were harvested at intervals from 1 to $48 \mathrm{~h}$ after pulse labelling. These were separated into stem (with node and petiole), leaf blades, carpels and seeds. In some experiments, the seeds were subdivided into seed coats and embryos (axes + cotyledons). The parts were digested overnight at $60^{\circ} \mathrm{C}$ in a $1: 1(\mathrm{v} / \mathrm{v})$ solution of perchloric acid and $30 \%(\mathrm{v} / \mathrm{v}) \mathrm{H}_{2} \mathrm{O}_{2}$ in sealed vials. The digested samples were then diluted with water and the radioac- tivity measured by scintillation spectrometry in a fluor solution consisting of $10 \mathrm{~g}$ PPO (2,5-diphenyloxazole), 11 Triton $X-100$ and $2 I$ toluene. Counting efficiencies, determined by addition of internal ${ }^{32} \mathrm{P}$ standards, ranged from 70 to $80 \%$. Since phosphate uptake into explants varied considerably, results are expressed as the percentage of total ${ }^{32} \mathrm{P}$ found in the different parts of an explant.

Determination of water loss. Rates of water loss from excised leaves sealed at the cut end with vaseline and similarly treated pods were determined gravimetrically (Neumann 1974).

All data are means \pm SE from the assay of 3 explants excised from separate plants.

\section{Results}

Kinetics of phosphate movement. Single pod explants were given a $15-\mathrm{min}$ pulse of ${ }^{32} \mathrm{Pi}$ via the cut base of the stem and were assayed after 1,5 and $24 \mathrm{~h}$ chase periods in distilled water. After the first hour, $75 \%$ of the ${ }^{32} \mathrm{P}$ taken up was found in the leaf blades with most of the remainder in the stem and petiole (Fig. 1). During the same period, the pods accumulated about $3 \%$ of the counts with $2 \%$ in the carpels and $1 \%$ in the seeds. The percentage of ${ }^{32} \mathrm{P}$ in the blades remained fairly constant between 1 and $5 \mathrm{~h}$ but decreased between 5 and $24 \mathrm{~h}$. The percentage of ${ }^{32} \mathrm{P}$ in stems and petioles remained fairly constant between 1 and $24 \mathrm{~h}$, whereas the percentage of ${ }^{32} \mathrm{P}$ in seeds increased steadily. The percentage of ${ }^{32} \mathrm{P}$ in the carpels showed a small increase be-



Fig. 1. Distribution of a 15 -min pulse of ${ }^{32} \mathrm{P}_{\mathrm{i}}\left(3.7 \times 10^{4} \mathrm{Biq}\right.$ $\mathrm{mil}^{-1}$ in $0.1 \mathrm{~m} M \mathrm{KH}_{2}, \mathrm{PO}_{4}$ ) into parts of explants (taker at mid podfill) during a $24 \mathrm{~h}$ incubation in distilled $\mathrm{H}_{2} \mathrm{O}$. Vertical bars indicate $\operatorname{SE}(\mathrm{n}=3)$ 


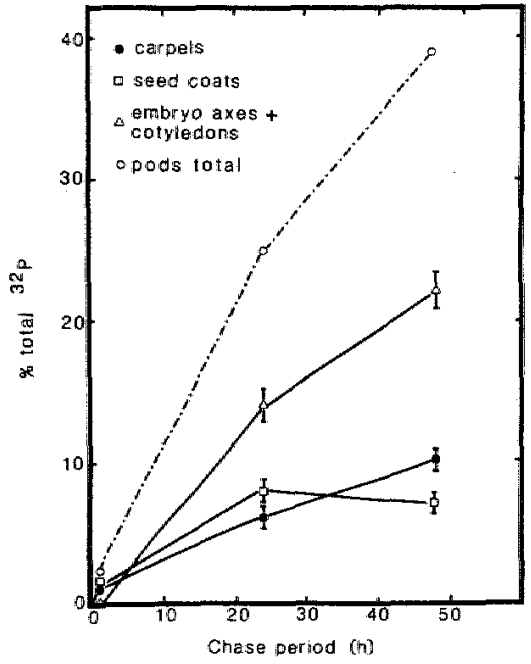

Fig. 2. Distribution of a $15-\mathrm{min}$ pulse of ${ }^{32} \mathrm{P}\left(3.7 \times 10^{4} \mathrm{~Bq} \mathrm{~m}^{-1}\right.$ in $\left.1.0 \mathrm{mM} \mathrm{KH} \mathrm{KH}_{4}\right)$ into the pods during a $48 \mathrm{~h}$ incubation in distilled $\mathrm{H}_{2} \mathrm{O}$. Explants taken at mid-podfill. Vertical bars indicate $\operatorname{SE}(n=3)$

tween 5 and $24 \mathrm{~h}$. Figure 2 shows the relative distribution of a $15-\mathrm{min}{ }^{32} \mathrm{Pi}$ pulse within the pods of explants after 1,24 and $48 \mathrm{~h}$ incubation periods in water. Both the carpels and seed coats became labelled during the first h $\left(1 \%\right.$ of total ${ }^{32} \mathrm{P}$ in each), while the embryos (axes + cotyledons) did not. However, the percentage of ${ }^{32} \mathrm{P}$ in the embryos rose steadily between 1,24 and $48 \mathrm{~h}$. By contrast, the percentage of ${ }^{32} \mathrm{P}$ in the seed coat increased between 1 and $24 \mathrm{~h}$ and then levelled off between 24 and $48 \mathrm{~h}$.

Xylem and phloem paihways of distribution. Gravimetric determinations of evaporative water loss, as an estimate of xylem flux distribution to leaves and pods, gave average values of $11 \mathrm{mg} \mathrm{min}^{-1}$ and $0.5 \mathrm{mg} \mathrm{min}^{-1}$ respectively, i.e. a ratio of $22: 1$. To determine the relative contribution of phloem transport out of the leaves to accumulation in the pods, the phloem in the petioles of a batch of explants was disrupted by steam girdling one $h$ after pulse labelling; in this way, translocation of ${ }^{32} \mathrm{P}$ out of the leaf blades via the phloem was prevented.

Table 1 shows that $2 \%$ of ${ }^{32} \mathrm{P}$ in the explants was located in the pods after $1 \mathrm{~h}$ (the time at which the steam girdling was done). After $24 \mathrm{~h}$, the percentage of counts in the pods had only risen to $6 \%$ in girdled explants compared with $18 \%$ for control pods. The percentage of ${ }^{32} \mathrm{P}$ in leaves of non-girdled explants remained the same between 1 and $24 \mathrm{~h}$ after the ${ }^{32} \mathrm{P}$ pulse. By contrast, the ${ }^{32} \mathrm{P}$ content in leaves of girdled explants rose from $66 \%$ at $1 \mathrm{~h}$ to $82 \%$ of the total counts at $24 \mathrm{~h}$. The increase in ${ }^{32} \mathrm{P}$ percentage in the blades of girdled
Tab. 1. Effect of seed removal and petiole phloem destruction (steam girdling) on transport of a 15 -min pulse of ${ }^{32} \mathrm{P}_{i}(3.7 \times$ $10^{4} \mathrm{~Bq} \mathrm{ml} l^{-1}$ in $\mathrm{mM} \mathrm{KH}_{2} \mathrm{PO}_{4}$ ) in explants excised at late podfill $(63$ SD). Pulse supplied via the cut base of the stem and followed by 1 and $24 \mathrm{~h}$ in distilled water. A jet of steam for $15 \mathrm{~s}$ was used to kill a $1.5 \mathrm{~cm}$ segment abont midway allong the petioles. The seeds were excised after $1 \mathrm{~h}$ of $\mathrm{H}_{2} \mathrm{O}$ incubation. Vallues are means $\pm \operatorname{SE}(n=3)$.

\begin{tabular}{lccc}
\hline $\begin{array}{c}\text { Chase period } \\
\mathrm{h}\end{array}$ & \multicolumn{3}{c}{$\%$ of total ${ }^{32} \mathrm{P}$ in } \\
\cline { 2 - 4 } & $\begin{array}{c}\text { Stern }+ \\
\text { petiole }\end{array}$ & $\begin{array}{c}\text { Leaf } \\
\text { blades }\end{array}$ & Pods \\
\hline 1 & $32 \pm 2$ & $66 \pm 2$ & $2 \pm 0.6$ \\
24 & $20 \pm 1$ & $62 \pm 2$ & $18 \pm 2$ \\
24 (Petiole steam-girdled) & $12 \pm 4$ & $82 \pm 6$ & $6 \pm 2$ \\
24 (Seeds removed) & $31 \pm 2$ & $65 \pm 2$ & $4 \pm 0.6$ \\
\hline
\end{tabular}

explants coincided with a large decline in percentage ${ }^{32} \mathrm{P}$ content in stems and petioles.

Effect of seed removal. Removal of the seeds $1 \mathrm{~h}$ after pulse labelling had no effect on the percentage ${ }^{32} \mathrm{P}$ remaining in the leaf blades at $24 \mathrm{~h}$ compared with control explants (Tab. 1); however, seed removal increased the percentage of total counts in the stem and petiole. The percentage of ${ }^{32} \mathrm{P}$ in the carpels of explants with seeds removed increased only slightly between 1 and $24 \mathrm{~h}$.

Effect of pod number. Mid-podfill plants trimmed to either 1 or $2-3$ pods per node were pulsed with ${ }^{32} \mathrm{P}$ for $15 \mathrm{~min}$ and transferred to water for 5,24 or $48 \mathrm{~h}$ before analysis of ${ }^{32} \mathrm{P}$ distribution. Table 2 shows that large differences in pod load did not greatly affect the percentage of ${ }^{32} \mathrm{P}$ accumulated in the pods. Distribution of ${ }^{32} \mathrm{P}$ did not appear to be a function of the concentration of carrier phosphate used in the labelling solution since similar patterns were obtained using either $0.1 \mathrm{~m} M$ or $1.0 \mathrm{mM} \mathrm{KH_{2 }} \mathbb{P O}_{4}$ as carrier. The fact that accumulation into the pods continued between 24 and $48 \mathrm{~h}$ suggests

Tab. 2. Effect of number of pods per node on distribution of a 15 -min pulse of ${ }^{32} \mathrm{P}$ to pods. A pulse of $3.7 \times 10^{4} \mathrm{~Bq} \mathrm{ml}$ $\mathrm{H}_{3}{ }^{32} \mathrm{PO}_{4}$ in $0.1 \mathrm{mM}$ and $1 \mathrm{mM} \mathrm{KH}_{2} \mathrm{PO}_{4}$ respectively for experiments 1 and 2 was fed to explants at mid-pod fill (53 SD). Values are means $\pm \operatorname{SE}(n=3)$.

\begin{tabular}{lcccc}
\hline & $\begin{array}{c}\text { No. of } \\
\text { pods }\end{array}$ & \multicolumn{3}{c}{$\%$ of total ${ }^{32} \mathrm{P}$ in pods } \\
\cline { 3 - 5 } & & $\begin{array}{c}5 \mathrm{~h} \\
\text { chase }\end{array}$ & $\begin{array}{c}24 \mathrm{~h} \\
\text { chase }\end{array}$ & $\begin{array}{c}48 \mathrm{~h} \\
\text { chuase }\end{array}$ \\
\hline Experiment 1 & 1 & $11 \pm 2$ & $25 \pm 3$ & - \\
Experiment 2 & $2-3$ & $12 \pm 1$ & $26 \pm 5$ & - \\
& 1 & - & $25 \pm 2$ & $39 \pm 2$ \\
\hline
\end{tabular}


that ${ }^{32} \mathrm{P}$ remained available for transport to the pods during the 5 and 24 h experiments.

\section{Discussion}

\section{Partitioning of xylem-fed ${ }^{32} \mathbf{P}$ within the explants}

The results in Fig. 1 and Tab. 1 suggest that most of the phosphate supplied to explants via the transpiration stream initially accumulates in the leaves and is only subsequently transferred to the pods. This finding is in: agreement with the conclusions of Lewis and Pate (1973) and McNeil et al. (1979) who used excised legume shoots to follow the distribution of ${ }^{15} \mathrm{~N}$ - and ${ }^{14} \mathrm{C}$-labelled amino acids fed via the transpiration stream. The ratio of ${ }^{32} \mathrm{P}$ accumulation between leaf blades and pods during the first $\mathrm{b}$ after pulse labelling was 25:1 in favor of the leaf blades (from Fig. 1). This ratio $(25: 1)$ corresponded well with the distribution of transpirational flux between leaves and pods (22:1). Not surprisingly, most of the ${ }^{32} \mathrm{P}$ in the pods after the one-h pulse was in the transpiring carpels (which are fed by xylem connected with the stem xylem, Thorne 1981) rather than the seeds. After $24 \mathrm{~h}$, the ratio of ${ }^{32} \mathrm{P}$ distribution had declined to approximately $2: 1$ (due to increased accumulation in the pods), suggesting that most phosphate movement to the pods (particularly the seeds) occurs independently of transpiration and that the process is slower than transpiration. Results in Tab. 1 show that the distribution of xylem fed ${ }^{32} \mathrm{P}$ to the pods between 1 and $24 \mathrm{~h}$ was largely prevented by destroying (girdling) the phloem connection between the leaf and the pods. This indicates that most of the ${ }^{32} \mathrm{P}$ which accumulates in the pods is transferred from the leaves via the phloem. Direct transfer from xylem to phloem in the stem (or even in the petiole) could, however, be more significant when transpiration rates are low (unpublished results by present authors). Nonetheless, our data do not support the idea that the pods compete directly with the leaves for the supply of minerals, such as phosphate, coming up from the roots (Noodén 1980).

\section{Pathway of ${ }^{32} \mathrm{P}$ in the pods}

Figure 2 shows clearly that the carpels and seed coat had accumulated some ${ }^{32} \mathrm{P} 1 \mathrm{~h}$ after pulse labelling, whereas the embryos (axes + cotyledons) had not. The subsequent labelling of the embryos suggests that ${ }^{32} \mathrm{P}$ accumulates in the seed coats prior to translocation into the embryo. This agrees with the pattern for distribution of photosynthetic assimilates in bean and soybean seeds (Patrick and McDonald 1980, Thorne 1980). Although changes in the distribution of ${ }^{32} \mathrm{P}$ in the seeds of explants were slower than for ${ }^{14} \mathrm{C}$-sugars in seeds of intact plants (Thorne 1980), our results support the contention that the seed coat is the site of phloem unloading and that it acts as a conduit to the embryo for phosphate as well as photosynthate (Thorne 1980,
1981). The role of the carpels in the transfer of assimilates is less clear, and even though they may serve as an intermediary for $\mathrm{Pi}$ en route to the seed coats they are not major sites of accumulation.

\section{Regulation of ${ }^{32} \mathbf{P}$ export to pods}

The effects of altering the source/sink ratio on rates of $\mathrm{CO}_{2}$ fixation and translocation to the pods have been extensively investigated in soybean (Kollman et al. 1974, Fellows et al. 1979, Streeter and Jeffers 1979, Peet and Kramer 1980, Setter et al. 1980). Studies on mineral distribution, however, have mainly considered the long-term effects of varied source-sink ratios on distribution (Kollman et al. 1974, Derman et al. 1978), and these may not represent the short-term mechanisms controlling transport rates of mineral assimilates. In soybean explants given a pulse of ${ }^{32} \mathrm{P}_{\mathrm{j}}$, llarge differences in the pod load or pod-leaf ratio did not produce proportional changes in accumulation of newly assimilated ${ }^{32} \mathrm{P}$ by the pod during short-term experiments of $5-24 \mathrm{~h}$ (Tab. 2). Conversely, total removal of the seeds did not prevent an apparent redistribution of ${ }^{32} \mathrm{P}$ from the leaf blades into the stem and petiolar tissues (cf. phloemgirdled and deseeded explants in Tab. 1). Thus the factors limiting accumulation of currently assimilated ${ }^{32} \mathrm{P}$ in the seeds of soybean explants appear to be located primarily in the source leaves (cf. Greenway and Gunn 1966). Mesophyll unloading or phloem loading processes (Lüttge and Higinbotham 1979) may possibly be involved.

Our results are consistent with the observation that a 2-3-fold increase in "strength" or "size" of the pod "sink" does not accelerate senescence in explants (Neumann et al. 1983) or intact plants (Lindoo and Noodén 1977, Noodén et al. 1978). Moreover, our data provide no direct evidence in favour of the idea (nutrient diversion theory, Nooden 1980) that the pods can cause monocarpic senescence by directly diverting the flow of nutrients such as phosphate coming up from the roots through the xylem, away from the leaves.

Acknowledgements - Financial support from Allied Chemical Corp. is gratefully acknowledged.

\section{References}

Derman, B., Rupp, D. C. \& Noodén, L. D. 1978. Mineral distribution in relation to fruit development and monocarpic senescence in Anoka soybeans. - Am. J. Bot. 65: $202-213$.

Fellows, R. J., Egli, D. B. \& Leggett, I. E. 1979. Rapid: changes in translocation patterns in soybeans following source-sink alterations. - Plant Physiol. 64: 652-655.

Greenway, H. \& Gunn, A. 1966. Phosphorus retranslocation in Hordeum vulgare during early tillering. - Planta 71 : $43-67$. 
Hanway, J. J. \& Weber, C. R. 1971. N, P and K percentages in soybean [Glycine max (L.) Mert.] plant parts. - Agron: J. 63: $286-290$.

Hocking, P. I. \& Pate, J. S. 1977. Mobilization of minerals to developing seeds of legumes. - Ann. Bot. 41: 1254-1278.

Kollman, G. E., Streeter, J. A., Jeffers, D. L. \& Curry, R. B. 1974. Accumulation and distribution of mineral nutrients, carbohydrate and dry matter in soybean plants as influenced by reproductive sink size. - Agron. J. 66: 549-554.

Lewis, O. A. M. \& Pate, J. S. 1973. The significance of transpirationally derived nitrogen in protein synthesis in fraiting plants of pea (Pisum satirum L.). - J. Exp. Bot. 24: 596-606.

Lindoo, S. J. \& Noodên, L. D. 1976. The interrelationship of fruit development and senescence in Anoka soybeans. Bot. Gaz. 137: 218-223.

- \& Nooden, L. D. 1977 . Studies on the behaviour of the senescence signal in Anoka soybeans. - Plant Physiol. 59: 1136-1140

Lüttge, U. \& Higinbotham, N. 1979. Transport in Plants. Springer Verlag, New York. pp. 352-369. ISBN $0-387-90383-6$.

MeNeil, D. L., Atkins, C. A. \& Pate, J. S. 1979. Uptake and utilization of xylem-borne amino compounds by shoot organs of a legume. - Plant Physiol. 63: 1076-1081.

Neumann, P. M. 1974. Senescence of attached bean leaves accelerated by sprays of silicone oil antitranspirants. Plant Physicl. 55: 638-640.

- \& Noodén, L. D. 1981 . Factors contralling the distribution of xylem-fed ${ }^{32} \mathrm{Pi}$ to the pods of soybean explants. - Plamt Physial. 67 (Suppl.): 377.
- \& Ncodén, L. D. 1983. Interaction of mineral and cytokinin supply in control of leaf senescence and seed growth in soybean explants. - J. Plant Nutr. 6: 735-742.

- Tucker, T. \& Noodén, L. D. 1983. Characterization of leaf senescence and pod development in soybean explants. - Plant Physiol, 72: 182-185.

Noodén, L. D. 1980. Senescence in the whole plant. - In Senescence in Plants (K. V. Thimann, ed.), pp. 219-258. CRC Press, Boca Raton, Florida. ISBN 0-8493-5083-5.

- , Rupp, D. C. \& Derman, B. D. 1978. Separation of seed development from monocarpic senescence in soybeans. Nature 271: 351-354.

Patrick, J. W. \& McDonald, R. 1980. Pathway of carbon tramsport within developing ovules of Phaseolus vulgaris $\mathrm{L}$. - Aust. J. Plant Physiol. 7: 671-684.

Peet. L. M. \& Kramer, P. J. 1980. Effects of decreasing source sink ratio in soybeans on photosynthesis, photorespiration, transpiration and yield. - Plant Cell Environ. 3: 201-206.

Setter, T. L., Brun, W. A. \& Brenner, M. L. 1980. Stomatal closure and photosynthetic inhibition in soybean leaves induced by petiole girdling and pod removal - Plant Physiol. 65: 884-887.

Streeter, J. G. \& Jeffers, D. L. 1979. Distribution of total non-structural carbohydrates in soybean plants having increased reproductive loads. - Crop Sci. 19: 729-734.

Thorne, J. H. 1980 . Kinetics ${ }^{14} \mathrm{C}$ photosynthate uptake by developing soybean fruit. - Plant Physiol. 65: 975-979.

- 1981. Morphology and ultrastructure of matemal seed tissues of soybean in relation to the import of photosynthate. - Plant Physiol. 67: 1016-1025. 
This document is a scanned copy of a printed document. No warranty is given about the accuracy of the copy. Users should refer to the original published version of the material. 